talk to about my insects", he wrote in 1828; in 1831, on hearing he was off on the Beagle, another collecting friend Frederick Watkins wrote to Darwin, "Woe unto ye Bettles of South America, woe unto all tropical butterflies". Despite Henslow's inspiring Cambridge lectures in botany, and despite Darwin's brief geological tour of Wales with Adam Sedgwick, the Darwin who set out on the Beagle was first and foremost an entomologist. He very quickly became much more of a geologist, partly through the influence of Lyell's Principles of Geology (three volumes 1830-1833), the first volume of which FitzRoy gave him just before the Beagle set sail (the other volumes being sent to him in South America), but mainly through the sheer impressiveness of the geological formations and activity the voyage offered. "There is nothing like geology", he wrote home in 1834; "the pleasure of the first days partridge shooting or the first days hunting cannot be compared to finding a fine group of fossil bones, which tell their story of former times with almost a living tongue."

Darwin's transformation from beetle collector to rounded naturalist is strikingly demonstrated in the volume. Equally significant, however, is the light it sheds on his circle: family, more distant relations and friends. The letters remind us that the sage of Down House was once a carefree young man who lay in the strawberry patches and played Housemaid and Postillion with Fanny Owen. His letters to her are lost, but Fanny's to Charles survive (mostly with strict instructions for him to burn them instantly once he has read them). One wonders what he felt when, barely a year at sea, he received his sister's letter informing him that the girl he described as "la belle Fanny", "the prettiest, plumpest, Charming personage that Shropshire possesses" was engaged to another. Fanny's letters suggest Charles was infinitely better off with Emma Wedgwood, still a shadowy figure in Volume 1. Her time will undoubtedly come in Volume 2.

This lapse into the language of romance is entirely appropriate, for these letters reflect a real world very like the one created by Jane Austen. Darwin's sisters took it in turn to write him each month, and their long and newsy letters are full of the stuff of the social history of upper middle class, provincial England during the 1830 s. They send him news of the Reform Bill and the cholera epidemic, but also of engagements and marriages, births and deaths, balls and visits. His sisters despair as the voyage stretches from two to three to five years; and Darwin's own stiff upper lip begins to quiver as seasickness persists, the novelty fades and (after the visit to the Galapagos Islands), the scientific returns decrease exponentially. "In short, I am convinced it is a most ridiculous thing to go round the world, when by staying quietly, the world will go round with you." He penned this prophetic sentiment in the penultimate letter he wrote home, in July 1836.

This volume is teeming with life and exuberance. There is little of the ill health that was to plague Darwin's later years, and, because his correspondents are allowed to speak for themselves, much about his early circle, from his irascible and fascinating brother Erasmus to his

\section{Happy repitition}

\section{David L. Hull}

The Survival of Charles Darwin: A

Biography of a Man and an Idea.

By Ronald W. Clark.

Random House/Weidenfeld \& Nicolson: 1985. Pp.449. \$19.95, £14.95.

BIOGRAPHIES of Charles Darwin have become as stylized and predictable as kabuki theatre - Darwin's comfortable childhood, his lazy days at Cambridge, the happy accident that put him on board the Beagle, his return to England after his arduous voyage, his marriage and retreat to Victorian gentility at Down House, his mysterious illness, the long gestation of the Origin of Species, Wallace's bolt from the blue, T.H. Huxley taking on "Soapy Sam" at the 1860 meeting of the British Association for the Advancement of Science, the eventual triumph of Darwin's theory, Darwin's later publications, his death and burial at Westminister Abbey. Clark's biography is no exception, although he does strew this familiar narrative with interesting titbits. For example, anyone reading Darwin's Life and Letters might notice that Darwin called his residence near the village of Downe in Kent "Down House", instead of "Downe House", and wonder why. Clark explains that the village was "Down" until 1842 when the government added the " $e$ " to distinguish the village in England from the quietly supportive father to his wonderfully demonstrative sisters. The letters are finely edited and presented, even if the explanatory editorial apparatus could profitably have been fuller. Several appendices provide additional information for these years, including the main events of his life, a list of books and people on board the Beagle, and biographical details of those with whom he corresponded or who are mentioned in the letters. The family connections can now be additionally sorted out with the aid of Richard Freeman's new book, Darwin Pedigrees. This reprints the scarce pedigree first produced in 1888 by H.F. Burke, and incorporates Freeman's own researches, particularly on later Darwins and on female members of the family.

For some years now, historians have referred (sometimes disparagingly) to the Darwin Industry. All it needed, it seems, was an injection of foreign capital to show itself alive, well and an immensely fruitful activity.

W.F. Bynum is at the Wellcome Institute for the History of Medicine, London. county in Ireland. There was, after all, the continuing Irish Problem. Darwin refused to adopt the new spelling for his own house.

Clark does not stop with Darwin's death in 1882. His book is the biography of a man, but it is also the biography of an idea. $\mathrm{He}$ traces the decline of evolutionary theory towards the end of the nineteenth century, its rough treatment at the hands of such Mendelians as William Bateson, the resurgence of Lamarckism, the "Monkey Trial" in Tennessee, the increasing influence of mathematics on the theory and the formation of the Modern Synthesis. He concludes with two chapters, one entitled "Molecular Biology Takes Over" and a second in which he describes recent controversies over the tempo of evolution and over cladistic analysis. These discussions are necessarily somewhat cursory, and some evolutionary biologists might protest that molecular biology has not taken over their field. The most that can be said is that molecular data have been incorporated into traditional views of the evolutionary process. With respect to the pace of evolution, Clark shows that emphasis on slow, gradual evolution has alternated periodically with more saltative views. Eldredge and Gould's punctuational model is but one more swing of the pendulum.

Another theme that recurs in the book is the social responsibility of scientists. Scientists do not publish in a social vacuum. Other experts read their work but so do theologians, reporters, high-school teachers and politicians. For example, the 
anonymous reviewer of Darwin's Descent of Man (1872) in the London Times chastized Darwin for being "reckless" in publishing such "disintegrating speculations" in such perilous times. Fifty years later and an ocean away, Bateson was to be given a similar lesson when he claimed at a meeting of the American Association for the Advancement of Science that the "origin and nature of species remains utterly mysterious". As might be expected, newspaper headlines declared triumphantly "Darwinism Disproved".

Another 50 years on the scenario was replayed when critics of sociobiology warned that statements made by E.O. Wilson and company could easily be used by racists and

\section{IMAGE \\ UNAVAILABLE FOR \\ COPYRIGHT REASONS}

Down House, at Downe in Kent, Darwin's home from 1842 until his death in 1882.

sexists. These criticisms in turn were taken up by Creationists as more proof that evolutionary theory is false. Even more recently, advocates of a new theory of biological classification termed "cladistics" have proclaimed that cladistic classifications are not about evolution but about patterns of character distributions, no matter how thay may have arisen. Rumours of Darwin's death in South Kensington were a result. More recently still, Tom Bethell in Harper's has complimented cladists for having a truly scientific outlook. "Only evolutionary agnostics like Patterson and Nelson and other cladists seem willing to live with doubt. And that, surely, is the only truly scientific outlook." As far as Bethell is concerned, the proper attitude towards evolution is the one that Huxley advocated for the existence of God - not proven. On these standards, very little has been proven in science, including relativity theory, quantum theory, not to mention continental drift. The authenticity of the Shroud of Turin is quite another matter. There is no doubting here.

Once again, Creationists are sure to make ample capital out of this intramural dispute among scientists. But what are scientists to do? No matter how judiciously they present their views, no matter how technical the journal, their statements can always be misused by those whose political or religious convictions outweigh considerations of intellectual integrity. If nothing else Clark's history of Darwinism shows that scientific disputes continue, as do marriages and divorces according to $\mathrm{Dr}$ Pangloss, in happy repitition.

David L. Hull is a Professor of Philosophy at Northwestern University, Evanston, Illinois.

\section{The conversation continued}

\section{Philip Kitcher}

The Nature of Selection: Evolutionary

Theory in Philosophical Focus.

By Elliott Sober.

MIT Press:1984. Pp.383. \$33.75, £30.

VIRTUALLY no philosopher is immune to the fear of irrelevance. Despite the reassurance that one is grappling with problems that have challenged the Western intellectual tradition since the time of the Greeks, there is always the quiet voice that asks "Does anyone care?". So it is tempting to announce that philosophy is - and perhaps has always been - the servant of the sciences, and to immerse oneself in the theoretical problems that arise within some more self-confident domain of inquiry. Even this may not put an end to the whispered doubts. If philosophers turn meta-scientists, do they manage to contribute anything that a reflective practitioner could not have achieved more easily? Is philosophy only useful when it tidies the corners that talented scientists are too busy to set in order for themselves?

A long and distinguished tradition in the philosophy of science reveals the impact of combining philosophical understanding with deep knowledge of the sciences. The tradition is strongest in the philosophy of physics, where reflections on space, time, cause and chance have proven valuable both to science and to philosophy. More recently, there has been a fruitful alliance between philosophy and psychology, in which students of cognitive science have looked to philosophers for conceptual guidance, offering in return new perspectives on old problems about mind, language and knowledge. The publication of Elliott Sober's new book shows that biology's turn has now come.

On reading a draft of The Nature of Selection in the autumn of 1983, I formed the opinion that it would illuminate both biology and philosophy. That impression is amply confirmed by study of the published version. Sober has focused evolutionary theory for philosophers, and thereby provided new material for inquiry into the general problems of the philosophy of science, the problems of explanation, confirmation and theory structure. He has also addressed a number of major conceptual problems that currently confront practising biologists. In his hands, some disputes about natural selection are reformulated; others are dissolved.

Sober's main project is to understand the causal notions that figure in evolutionary theory. He starts from the conviction that many contemporary debates about the evolutionary process persist because the protagonists have failed to understand the character of the causal claims that they and their opponents are making. The first part of the book is devoted to an analysis of the concepts of selection, adaptation and fitness, and to a delineation of the role that these concepts - as well as the concept of chance - play in evolutionary theory. The second part develops the analysis in the context of a dispute to which Sober has made substantial contributions, the controversy about units of selection. Substantial though that previous work was, the present discussion supersedes it.

On Sober's account, evolutionary theory is best construed as a theory of forces. Evolution is a process in which typically (though not invariably) gene frequencies change along a lineage, and evolutionary theory attempts to specify the forces that produce the changes. An immediate consequence of this perspective is that the old problem about the evolutionary tautology is broached and quickly disposed of. (Those who are tempted to use the term "tautology" in discussions of evolution ought to be required to read Sober's second chapter.) A more important result is the distinction between selection of and selection for. Selection of $o b$ jects contrasts with selection for properties. The distinction can be made by considering the electorate of the United States. American voters appear to select candidates who are bereft of foresight and understanding. Yet there is no selection for lack of foresight. The property selected for is surely telegenicity.

Although there are several other discussions in the first part of the book that will interest scientific readers, it is probable that they will think of the second part as where the action is. Sober's approach to the problem of units of selection starts with a chapter, allegedly designed to alienate all parties to the controversy, in which he tries to uncover confusions and fallacies in all the major positions. He continues with an analysis that makes explicit appeal to the concept of cause: a necessary condition for $\mathrm{X}$-selection (group selection, genic selection, species selection and so forth) is that there should be some property of Xs that is a positive causal factor on the survival and reproduction of organisms. (Sober eventually generalizes, allowing for entities other than organisms to serve as "benchmarks" of selection.)

However, the concept of cause cannot be

- The Royal Historical Society has published a collection of correspondence to complement Jack Morrell and Arnold Thackray's Gentlemen of Science: Early Years of the British Association for the Advancement of Science (published in 1981 by Oxford University Press and reviewed in Nature 294, 19; 1981).

In Gentlemen of Science: Early Correspondence Morrell and Thackray have gathered together "what [they] judge to be the 294 letters of greatest significance to the student of early Victorian science and culture", focusing upon letters written by and to William Vernon Harcourt, a pivotal figure in scientific matters during the early and middle nineteenth century. 